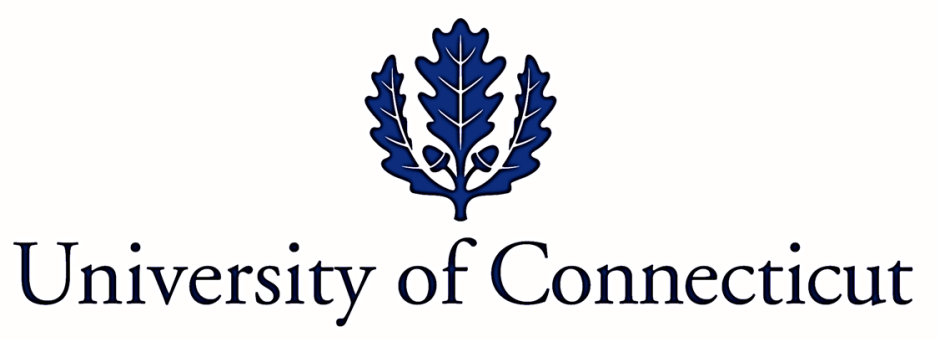

Department of Economics Working Paper Series

Evidence and Actions on Mortgage Market Disparities:

Research, Fair lending Enforcement and Consumer Protection

by

Marsha J. Courchane

CRA International

Stephen L. Ross

University of Connecticut

Working Paper 2018-14

August 2018

365 Fairfield Way, Unit 1063

Storrs, CT 06269-1063

Phone: (860) 486-3022

Fax: (860) 486-4463

http://www.econ.uconn.edu/

This working paper is indexed in RePEc, http://repec.org 


\title{
Evidence and Actions on Mortgage Market Disparities: Research, Fair lending Enforcement and Consumer Protection.
}

\author{
Marsha J. Courchane ${ }^{\mathrm{a}}$ and Stephen L. Ross ${ }^{\mathrm{b1}}$
}

\begin{abstract}
In this article, we present overviews of the research on discrimination in mortgage underwriting and pricing, the experiences of minority borrowers prior to and during the financial crisis and federal efforts to mitigate foreclosures during the crisis. We next discuss the history of legal cases alleging disparate treatment of minority borrowers, and recent cases alleging disparate impact in the wake of the Supreme Court's "Inclusive Communities" decision. Using these discussions as a background, we discuss and examine mortgage regulations issued by the Consumer Finance Protection Bureau following the financial crisis, describe recent developments in the FinTech industry discussing their implications for fair lending policy and minority borrowers more generally, and finally draw conclusions and make recommendations for improving the mortgage market outcomes of minority borrowers and increasing minority borrowers' access to credit.
\end{abstract}

JEL Codes: G01, G21, G23, G28, J15, J16, K23, K25, L85, R30

Keywords: Fair Housing Act, Mortgage Discrimination, HMDA, Risk-based Pricing, Financial Crisis, Mortgage Foreclosure, Subprime Lending, HAMP, Legal Settlements, Disparate Impact, Inclusive Communities, Consumer Finance Protection Bureau, FinTech.

${ }^{a}$ Financial Economics Practice, Charles River Associates, Washington, DC; ${ }^{b}$ Department of Economics, University of Connecticut, Storrs, CT

\footnotetext{
${ }^{1}$ Corresponding author: Stephen L. Ross, Department of Economics, University of Connecticut, Storrs, CT. 860-
} 486-3533, stephen.I.ross@uconn.edu 
The Fair Housing Act, enacted in 1968 as Title VIII of the Civil Rights Act, prohibits discrimination in the sale or rental of housing, and in residential real estate related transactions and brokerage services, based on protected classes, including race, color, religion, sex, familial status or national origin. ${ }^{2}$ While this Act has been in force for fifty years, the mortgage market and the nature of discrimination in this market has changed over time, and the Fair Housing Act's role in addressing racial and ethnic disparities has evolved with the market. Further, academic research on mortgage market disparities increasingly suggests that the large, observed market wide differences in minority outcomes cannot be simply attributed to differential treatment based on race or ethnicity. In the future, the mortgage market will continue to evolve and the recent growth of FinTech lenders and their initial forays into mortgage markets exemplifies such change. As with previous market innovations, the focus of fair lending monitoring and enforcement activities will need to change, and the factors that drive mortgage market disparities are likely continue to evolve.

We focus first on the most central aspects of research on discrimination in mortgage markets: mortgage underwriting and pricing. We also look at more recent areas of research, including the implications of the growth of the subprime sector for minority borrowers, as well as mortgage servicing and lender foreclosure. We tie some of the issues from the research arena to examples of litigation from the past decade - some of which allege disparate treatment by specific lenders and others that may have resulted from changes in underwriting and pricing outcomes that arose prior to the financial crisis. Next, we consider recent financial market reforms and their implications for minority borrowers. Finally, we offer some insights to how one would change the focus of research to incorporate recent changes in the use of data and analytical techniques, as incorporated by FinTech lenders.

\section{A. Race, Ethnicity and Loan Underwriting Outcomes}

The Financial Institutions Reform, Recovery and Enforcement Act (FIRREA) in 1989 expanded the Home Mortgage Disclosure Act (HMDA) data and significantly changed the landscape of research on and supervision meant to prevent mortgage lending discrimination. ${ }^{3}$ Prior to this time, research on discrimination in underwriting was limited to a very small number of lender-specific studies, or simply used aggregate information on denial rates provided under the earlier regulations. ${ }^{4}$ As of 1990 , lenders were required to report the underwriting outcomes at the individual loan level and federal regulators were required to release this information to the public. The early HMDA data identified widespread racial differences in the underwriting outcomes nationwide (Avery, Beeson and Sniderman, 1996) leading to some calls for increased anti-discrimination enforcement.

However, HMDA data collected prior to 2018 are quite limited in the information reported on individual loans, and as a result many of the racial and ethnic differences in loan denials reflected differences in the credit quality and loan characteristics of mortgage applicants. The Federal Reserve Bank of Boston set out to test this proposition by selecting a sample of loan applications from HMDA in the Boston metropolitan area and requesting banks in the Boston area to provide information from the loan application files for selected applications. The Boston Fed study controlled for a wide array of

\footnotetext{
2 The Fair Housing Act, 42.U.S.C. 3601-3619, was enacted as Title VIII of the Civil Rights Act of 1968.

${ }^{3}$ HMDA was enacted in 1977 and implemented under the Federal Reserve Board's (FRB's) Regulation C. Rulemaking authority for Reg. C moved to the Consumer Financial Protection Bureau (CFPB) in 2011.

${ }^{4}$ See FFIEC, History of HMDA, 2018.
} 
underwriting variables including credit history, loan-to-value (LTV) ratios, and housing expense and debt-to-income (DTI) ratios. The study found that blacks with the same application attributes as whites would have had a $19 \%$ average denial rate as compared to an $11 \%$ average denial rate for whites. The authors concluded that differences in the creditworthiness of black borrowers could not explain fully the racial differences in mortgage market outcomes (Munnell, Browne, McEneaney, and Tootell, 1992). ${ }^{5}$

The study was very controversial, and led to a considerable literature, which is far too extensive to explore here. ${ }^{6}$ For our purposes, we wish to focus on a specific critique made by Horne (1997) that much of the racial differences identified in the study could be explained by a lender reported variable indicating whether or not the borrower met the lender's credit guidelines. Horne argued that the power of this "meets guidelines" variable to explain racial differences suggested that the Boston Fed study had missed critical underwriting variables. Browne and Tootell (1995) made the counter-argument that the lender answered this question long after having approved or denied the loans, and if they saw a denied minority loan application that looked like it should have been approved they could validate their earlier decision by claiming that the application did not meet the lender's guidelines.

Ross and Yinger (2002) concluded that the "meets guidelines" variable indeed could explain substantial racial differences. However, their analysis suggested that the explanatory power was not due to omitted variables, but rather due to lenders differing in their loan underwriting standards and minority applicants being poorly matched to lenders relative to white applicants. Similarly, Blackburn and Vermilyea (2004) used a sample of loans drawn from several lenders as part of regulation by the Office of the Currency of the Comptroller and estimated individual lender specific and pooled underwriting models. The racial differences in the pooled models are quite large, but when underwriting models were allowed to vary across lenders most of the estimated racial differences disappeared, even in models that are substantially more parsimonious than the Boston Fed specification.

The natural question to ask is why black borrowers, and, in some cases, minority borrowers in general, appear to have done a much worse job of identifying lenders who are likely to approve their applications. Yezer, Phillips and Trost (1994) provided a potential explanation. They argued that loan application terms are not exogenous attributes of a loan application. Rather, borrowers typically only provide general preferences and detailed financial characteristics when inquiring about obtaining a mortgage from a lender or mortgage broker. The loan officer is likely to help the borrower put together a mortgage application that has a high likelihood of being approved, while a broker may shop an application around to several lenders in order to find the lender who is likely to accept the application. If minority borrowers get less assistance in this process, then those borrowers would naturally have a worse fit between their loan application attributes and the lender's specific standards. Consistent with this view, Ross, Turner, Godfrey and Smith (2008) and Hanson and Hawley (2016) both found in randomized field studies that minority borrowers received less information and assistance.

\section{B. Race, Ethnicity and Loan Pricing Outcomes}

Until the 1990s, the vast majority of mortgage lending activity in the U.S. occurred in either the government-insured mortgage market segment (including Federal Housing Administration (FHA) or

\footnotetext{
${ }^{5}$ A revised version was published by Munnell, et al. (1996) in the American Economic Review.

${ }^{6}$ See Ross and Yinger (2002) for a survey of this literature.
} 
Veterans Administration (VA) loans) or in the conventional, conforming mortgage market segment, in which loans were purchased and securitized by one of the large government sponsored enterprises (GSEs). The two types of products typically serve different segments of the market. The mission of HUD's FHA mortgage lending, for example, has been to reach underserved borrowers who may be first-time homeowners or who may lack sufficient assets to provide a conventional downpayment at the time of home purchase. These borrowers may be disproportionately minorities. HUD's mission was reaffirmed by Carol Galante, then FHA Commissioner, who stated "FHA's mission is to make sure that there is access to affordable mortgage credit for underserved borrowers and communities." An FHA report by Golding, Szymanoski, and Lee (2014) discussed the FHA focus on first time homebuyers with low downpayments noting that "FHA has insured about 13 percent of all mortgage originations during the past 80 years, but it has funded more than 50 percent of all first-time homebuyer mortgages during this same time.... Because first-time homebuyers tend to have smaller savings from which to draw, FHA helps them secure first-time homeownership through the agency's relatively smaller downpayment requirement, which is 3.5 percent."

The exception to government-insured and GSE funded loans was primarily alternative higher loan amount products in very high cost housing markets like Los Angeles and San Francisco. Starting in the mid-1990s, but accelerating in the period from 2004 - 2006, a large and active non-conforming segment of the mortgage market developed, including both the underwriting of riskier loan applications that would have been rejected in the conforming sector and the expansion of the use of non-conforming loan products, such as interest only (IO), negative amortization, and low documentation mortgages. ${ }^{7}$ While historically the non-conforming market was concentrated in jumbo mortgages that exceed the maximum loan amount for conforming loans, the growing subprime and Alt-A markets increasingly captured market share from both FHA insured and GSE funded loans. Chart 1 below documents this change in shares of the market segments. ${ }^{8}$ Several studies have documented a greater incidence of loans from subprime lenders to minorities and in minority neighborhoods.

Unlike the conventional, conforming sector, which traditionally charged relatively uniform prices, the subprime and Alt-A segments utilized risk-based pricing, where the cost of credit depended on both traditional risk factors like credit scores and LTV ratios and on the detailed attributes of the mortgage product itself. In response to the growth of risk-based pricing, HMDA disclosure requirements were expanded again, effective in 2004, to require the reporting of the annual percentage rate (APR) of the mortgage, if the APR exceeded the interest rate on treasury bonds of comparable maturity by 300 basis points (above the "rate spread threshold"). The APR was calculated based on adding the effective price of closing costs (over the entire term of the mortgage) into the note rate. The APR threshold field was intended to capture the cost of credit for especially high cost loans that would be likely to arise in the Alt-A or subprime market.

Initial examination of the 2004 HMDA pricing data implied that, other things equal, blacks and Hispanics were more likely to obtain a rate spread reportable or high cost loan relative to white borrowers (Avery, Canner and Cooke 2005). Bocian, Ernst and Li (2008) controlled for underwriting

\footnotetext{
${ }^{7}$ There was a brief pause in the growth of this segment due to the 1997 Asian Monetary crisis.

8 In Chart 1, HEL refers to HELOCS; Conv./Conf. refers to the conventional conforming market segment.
} 


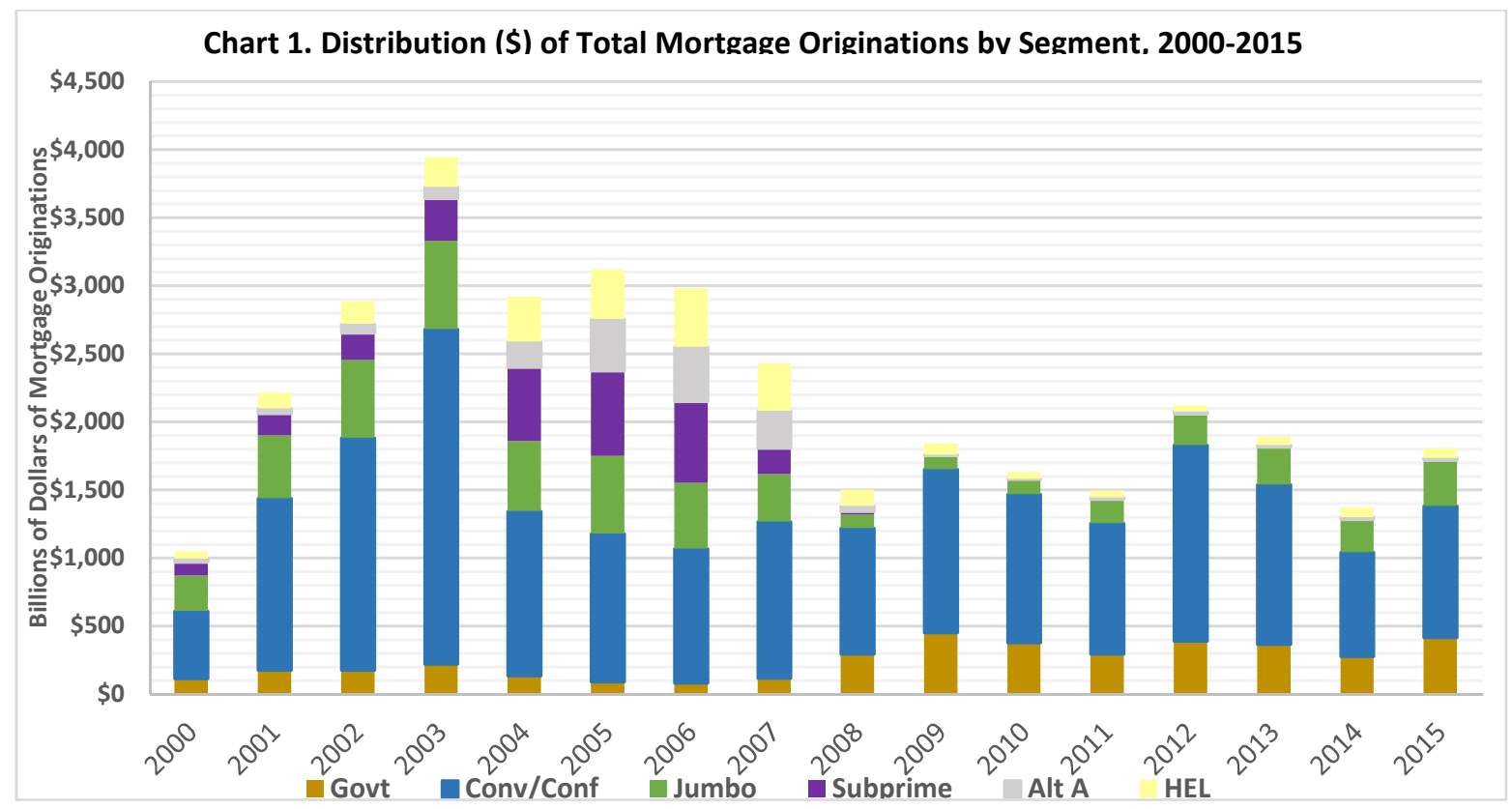

differences on factors like credit score and LTV by merging HMDA data to a proprietary database of securitized loans by subprime lenders. Most of their differences were concentrated in the home purchase segment of the market and, for blacks, among loan products with pre-payment penalties. They found that blacks were $17 \%-84 \%$ more likely to have a high cost loan than non-Hispanic whites and Hispanics were $52 \%-189 \%$ more likely depending upon the specific product. Haughwout, Mayer and Tracy (2009) conducted a similar analysis merging HMDA with securitized loans made by subprime lenders, but focused on a specific product type -- the $2 / 28$ adjustable rate mortgage. They did not find any evidence that blacks or Hispanics had higher note rates on their loans. ${ }^{9}$ Ghent, Hernández-Murillo and Owyang (2014) also examined racial differences in note rates across a variety of subprime mortgage products, and found small racial differences concentrated primarily in the home purchase and nondepository lender segments of the market. As they stated, "the relatively small effects we find can perhaps be viewed as a victory for mortgage regulation since the 1980s and 1990s when there was substantial evidence of discrimination against minorities." ${ }^{10}$

On balance, the evidence supports modest market wide differences in the cost of credit for black and Hispanic borrowers after controlling for standard risk factors. However, as with underwriting, these market wide findings tend not to persist for a given mortgage lender. Avery, Canner and Cooke (2005) examined racial and ethnic differences in the incidence of rate spread or high cost loans finding smaller differences when looking within lenders and product types. They suggested that a lender control might capture some omitted risk variables that affect price. Bhutta and Ringo (2014) and Bayer, Ferreira and Ross (2014) showed that even after controlling for standard mortgage risk factors, lender identity explains a majority of racial and ethnic differences in high cost lending. Similarly, Courchane (2007) used a multi-lender proprietary dataset to examine APR outcomes showing that a majority of the racial and

\footnotetext{
${ }^{9}$ As the authors look only at interest rate, they did not evaluate any differences among groups in closing costs.

10 Ibid., at p. 200.
} 
ethnic differences are associated with differential representation of minority borrowers in the subprime market, and with the racial and ethnic differences found in borrower risk factors.

Courchane (2007) examined the factors that contribute to the differential allocation of minority borrowers to high cost lenders and found that most of the racial differences across prime and subprime sectors can be explained by observable mortgage attributes including credit score, LTV and DTI. Courchane finds that these controls explain all but $1 \%(0.4 \%)$ of the initial $27 \%$ (16\%) racial (Hispanic) difference in the likelihood of being in the subprime market. The observables used included loan attributes that are typically associated with subprime loans, such as no documentation loans, prepayment penalties, and the wholesale channel. Reid and Laderman (2009) estimated a similar model of whether a borrower has a subprime loan in San Francisco. In their sample, the observables again including product attributes also significantly reduced the racial and ethnic differences -- from 34 to $7 \%$ and from 36 to $8 \%$, respectively. However, this tendency to be in the subprime market segment may arise from either borrower demand for these attributes and the riskiness of those neighborhoods or from subprime lenders' market penetration in these neighborhoods.

In a recent paper, Bayer, Ferreira and Ross (2018) developed a measure of lender's ex-post foreclosure risk in order to identify high risk lenders. Most of the across-lender racial differences in high cost lending were found to be attributable to the concentration of minority borrowers at these high cost lenders. In fact, controlling for high risk lender accounts for virtually all of the correlation between high cost lending and both non-depository lenders and lenders that primarily utilize non-agency or private label securitization. Significantly, these effects hold even when ex-post foreclosure risk is based on only white loans or only government or GSE (agency) securitized loans. The authors concluded that the higher prices charged by high risk lenders are likely attributable to these lenders drawing applications from unobservably riskier segments of the mortgage market.

Avery, Canner and Cooke (2005) examined racial and ethnic differences based on whether the loans were originated within the lender's Community Reinvestment Act (CRA) coverage area. They observed differences of only one-third the magnitude in the CRA coverage area sample relative to the rest of their sample of bank loans. They suggested that these differences might arise due to a channel effect, as most of the lenders' loans outside of the CRA coverage areas are originated through the wholesale lending channel. Similarly, Reid and Laderman (2009) find that loans outside of a bank's CRA assessment area are much more likely to be subprime loans, and both Courchane (2007) and Reid and Laderman (2009) find that loans originated through the wholesale lending channel are more likely to be in the subprime segment of the market. Courchane, Darolia and Zorn (2012) documented that wholesale loans are on average between 25 and 85 basis points more expensive than retail loans in the years leading up to the crisis. However, they also find that wholesale/broker lending is only modestly more concentrated among minority borrowers, and minority and low income neighborhoods. ${ }^{11}$ Further, Courchane (2007) shows that the majority of the higher price of wholesale loans is likely due to the concentration of wholesale lenders in the subprime segment of the market.

\footnotetext{
${ }^{11}$ See Courchane, Darolia, and Zorn (2012): In 2006, the share of wholesale loans for non-Hispanic white borrowers was $61 \%$ versus $71 \%$ for minority borrowers. The share of wholesale loans in middle income neighborhoods is $59 \%$ versus $29 \%$ in low income, and the share of wholesale loans in neighborhoods that are at least $50 \%$ non-Hispanic white is $59 \%$ versus $67 \%$ for neighborhoods that are at least $50 \%$ minority.
} 
In conclusion, while market wide differences exist, especially among wholesale loans, most of the unexplained differences are attributable to the disproportionate concentration of minority borrowers in the subprime market and/or risky subprime products. However, while these higher prices may be justified by the overall risk profile of the borrower population, they are borne by all subprime borrowers. If, as suggested in the previous section, minority borrowers are less successful in the prime market due to receiving less assistance, then prime-qualified minority borrowers may have been significantly overrepresented among subprime borrowers in the period leading up to the financial crisis. In fact, the traditional overrepresentation of minority borrowers in FHA may have stemmed, in part, from the failure of prime-qualified minority borrows to access modestly cheaper non-government conforming loans. It should not be surprising that the expansion of the subprime credit market also captured some prime qualified minority borrowers placing them in much more expensive loans.

\section{The Foreclosure Crisis and the Experiences of Minority Borrowers}

The fall in house prices beginning in 2006 coupled with rising unemployment during the great recession meant that borrowers could not easily refinance out of the adjustable rate mortgages that were typical in the subprime market. The traditional link of subprime adjustable rates to the London Inter Bank Offer Rate (LIBOR) exacerbated this problem during the financial crisis as banks became unwilling to extend short term credit and LIBOR rose substantially relative to U.S. Treasury rates. ${ }^{12}$ Delinquency and foreclosure rates began to rise as a consequence, and increasing numbers of homeowners became unable or unwilling to make their mortgage payments on time. Chart 2 provides information on the increased foreclosure activity. ${ }^{13}$ The subprime foreclosure inventory rate exceeded ten percent at the end of the first quarter of 2008, reached a peak of 15.58 percent by the end of 2009 , and then fell to just below seven percent by year-end 2016. To the extent that subprime loans were held disproportionately

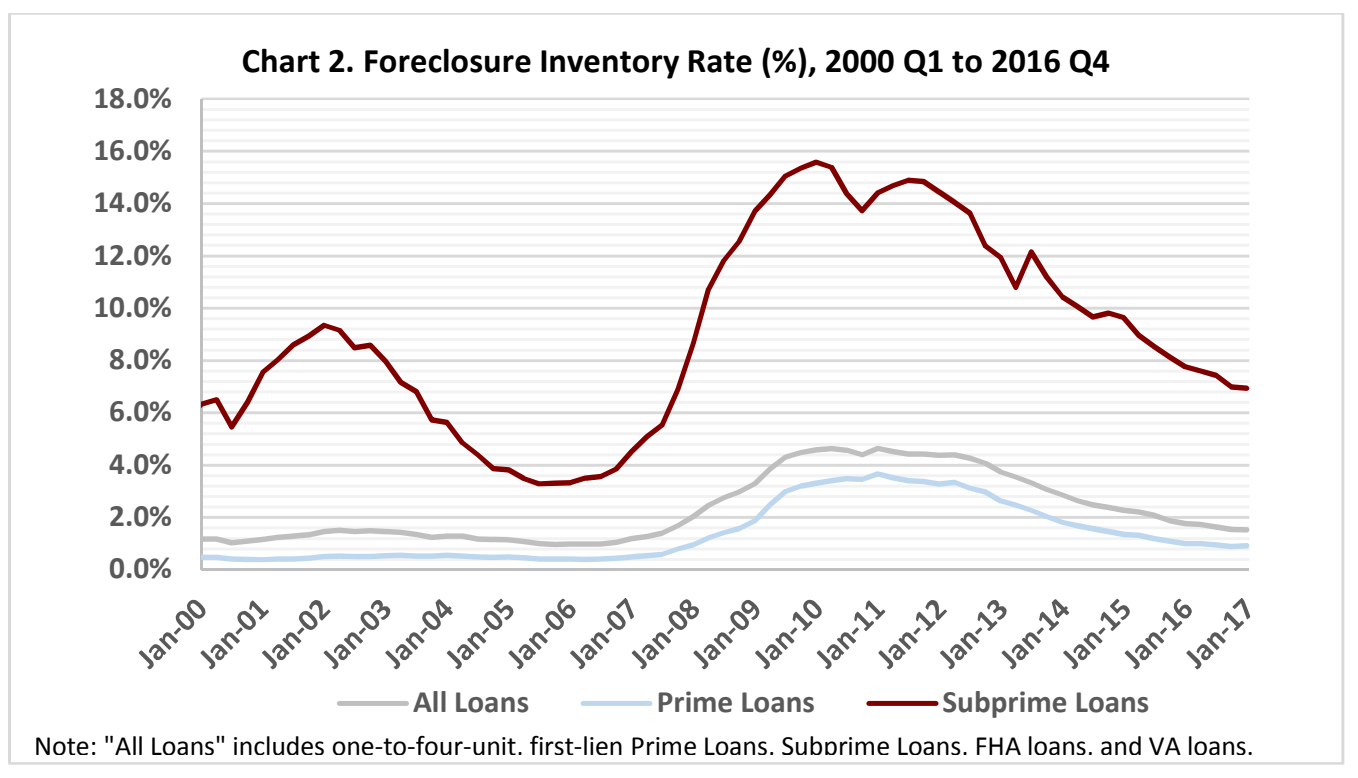

\footnotetext{
12 The evolution of mortgage products in the run up to the crisis and the collapse of the U.S. housing sector are both substantially detailed in United States Financial Crisis Inquiry Commission (2011).

${ }^{13}$ Mortgage Bankers Association (2018). National Delinquency Survey.
} 
by minority borrowers, this would imply that minority borrowers, and minority neighborhoods, would be impacted more severely by the foreclosure crisis. The large stock of loans in foreclosure likely continued to exert downward pressure on house prices for several years after the crisis.

The rising delinquencies after the mortgage market collapsed in 2008 put enormous pressure on all servicers to work with the thousands of borrowers with delinquent loans. Chart 3 provides information on seriously delinquent loans (180 DPD or more) of non-agency RMBS originated in 2000 or later. ${ }^{14}$ The need for changes in loan servicing led to the introduction of a federal program meant to help borrowers avoid foreclosure during the economic recession.

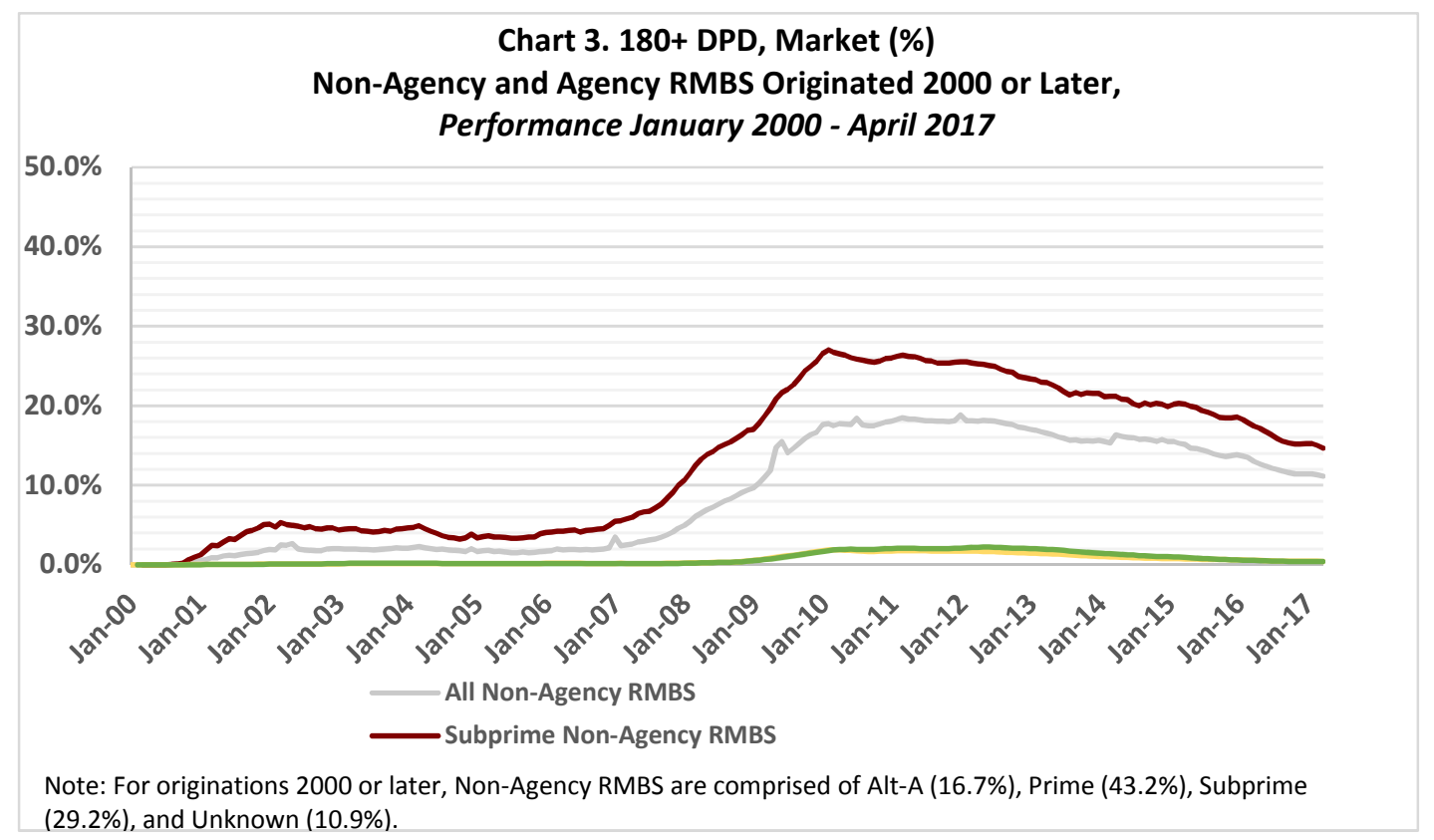

Many studies suggest that minority and low income neighborhoods experienced especially severe foreclosure rates during the crisis (see, for example, Chan, Gedal, Been and Haughwout 2013; Gerardi and Willen 2009; Fisher, Lambie-Hanson and Willen 2010; and Edmiston 2009). Bayer, Ross and Ferreira (2016) documented much higher rates of foreclosure for minority borrowers with differences in the home purchase market of 8.6 to 9.1 percentage points relative to an average foreclosure rate of $5.3 \%$ from 2005 to 2009. However, traditional risk factors and contemporaneous changes in housing prices and employment rates explained between 70 and 80 percent of these differences. The Center for Responsible Lending (CRL 2010) also looked at foreclosures by race/ethnicity using HMDA data and data on loan servicing (Lender Processing Services). They identified 2.5 million foreclosure completions from January 2007 through year end 2009, mostly on owner-occupied properties with first lien mortgages originated from 2005 - 2008. They estimated that 8 percent of both African Americans and Latinos had lost homes to foreclosures during that period as compared to 4.5 percent of whites.

\footnotetext{
${ }^{14}$ Non-Agency RMBS data are comprised of Moody's Structured Finance Non-Agency RMBS Loan Level data. The GSE data include Fannie Mae Single-Family Loan Performance Data and Freddie Mac Single Family Loan-Level Dataset are available at http://www.fanniemae.com/portal/funding-the-market/data/loan-performance-data.html and http://www.freddiemac.com/research/datasets/sf_loanlevel_dataset.html, last accessed June 22, 2018.
} 
Several studies find links between high neighborhood foreclosure rates and high-cost loans, subprime borrowers or subprime lenders. Reid and Laderman (2009) and Chan, Haughwout and Tracy (2015) find a substantial overlap between the neighborhoods where borrowers were more likely to obtain high cost loans and neighborhoods with high foreclosure rates. Mian and Sufi (2009) find both rapid mortgage credit expansion between 2002 and 2005 and high 2007 mortgage default rates in zip codes with large fractions of borrowers with subprime credit scores. Reid and Laderman (2009) show that loans from non-depository lenders have higher default rates than loans from traditional lenders in their CRA coverage areas, primarily explained due to the use of wholesale versus retail origination (mortgage brokers). Similarly, Jiang, Nelson and Vylacil (2014) document higher foreclosure rates at a major California lender for wholesale loans, in large part due to those loans being much riskier on traditional underwriting variables like credit score, LTV, and DTI. Given these patterns, subprime mortgages with little or no documentation and riskier terms may have contributed to the high levels of foreclosure in such neighborhoods (Been, Chan, Ellen and Madar 2011).

Several studies documented links between high foreclosure rates and traditional subprime loan features. Jiang, Nelson and Vytlacil (2014) documented substantially higher foreclosure rates among low and no documentation loans, with differences nearly twice as large in the wholesale segment of the portfolio. Further, Jiang, et al. (2014) model borrower reported income and show that income levels which are inconsistent with borrower attributes (potentially falsified) explains the differences in foreclosure rates. Similarly, LaCour-Little and Yang (2013) document rapid growth in the share of loans with reduced documentation between 2000 and 2007 and also find higher foreclosure rates for low documentation loans where reported income exceeds the borrower's predicted income. LaCour-Little, Calhoun and $\mathrm{Yu}$ (2011) examine loans that use subordinate debt in order to avoid paying for private mortgage insurance (piggyback loans). They find substantially higher foreclosure rates in zip codes with a larger share of subprime or non-owner occupied property piggyback loans.

However, the majority of the unexplained racial differences in foreclosure in Bayer, Ferreira and Ross (2016) arise for home purchase loans originated in 2006. ${ }^{15}$ These findings are somewhat surprising given that foreclosure rates of African-American borrowers began to rise substantially earlier, before 2006, than other groups. Their research suggests that more vulnerable borrowers selected into the market for owner-occupied housing as credit markets expanded, and if these borrowers tended to be concentrated in similar residential locations, then those locations would likely exhibit higher foreclosure rates during the crisis. Ferreira, Ross and Wang (2016) document a strong cross-sectional correlation between the market share of high cost lenders and subsequent foreclosure rates during the crisis. However, over half of this correlation can be explained by credit score, mortgage risk factors and borrower demographics, suggesting that much or all of the remaining correlation could be attributable to unobserved differences across neighborhoods, such as employment risk or non-housing wealth. In fact, Hoynes, Miller and Schaller (2012) conclude that labor market effects during and after the mortgage crisis were more severe for blacks and Hispanics than for whites. While the foreclosure crisis may have begun with falling housing prices and rising interest rates on subprime mortgages, the

\footnotetext{
${ }^{15}$ For refinance loans, they also find that the year of the original purchase, say 2002 versus 2005, is much more important for explaining racial differences in foreclosure than the origination date of the refinance mortgage.
} 
increasing levels of unemployment also had an impact - and one that would have differentially impacted minorities.

There exist contrasting views of the primary causes of the high levels of foreclosure among minority and low income borrowers and the high rates of foreclosure in disadvantaged neighborhoods. Some contend that the differences are driven heavily by risky mortgage products and higher costs of credit that were offered in subprime mortgage markets, while others contend they were caused primarily by minorities having lower credit scores, higher LTV and DTI ratios and higher levels of uncertainty in economics downturns. We believe that the evidence is more consistent with the latter explanation. We opine that, on average, minorities entered the crisis with significantly less housing equity, exposed to substantially higher debt burdens and simultaneously experienced much worse employment prospects during the crisis, all contributing to higher rates of default and foreclosure.

However, some authors have argued that the relaxed oversight of lenders and brokers allowed lenders to take advantage of minority borrowers given their historical lack of access to prime mortgage markets. Agarwal, Amromin, Ben-David, and Evanoff (2016) match denied loan applications to loans approved by a different lender a short time later. They identify loans as "steered" if the second lender belonged to the same bank holding company. "Steered" loans are less likely to go into delinquency, and on average are 50 basis points more expensive than "non-steered" loans. Further, "steered" loans tend to be products that are considered riskier and have higher profit margins, i.e. interest only (IO) mortgages, option ARM mortgages, mortgages with prepayment penalties or low/no documentation. Bostic, Engel, McCoy, Pennington-Cross, and Wachter (2008) conduct a nationwide study of the impact of anti-predatory lending laws comparing counties along state boundaries before and after the adoption of anti-predatory lending laws. They find that restrictions on loan features reduced loan originations of subprime loans, but that increases in the breadth of coverage actually increased originations, consistent with the elimination of loans with predatory features increasing demand by making the market appear safer (Ho and Pennington-Cross 2007). Agarwal, Amromin, Ben-David, Chomsisengphet, and Evanoff (2014) find that sending borrowers with low credit scores, histories of repeat refinancing or mortgages with negative amortization, pre-payment penalties or high closing costs to a counselling program reduced originations in half, leading to fewer loans with these features, as well as a reduction in subsequent foreclosure rates. Taken together, these papers are consistent with minority borrowers paying more for credit because they had less access to prime mortgage credit or less information on mortgage markets.

In spite of the evidence above, it is hard for us to view the general relaxation of underwriting standards and expansion of the subprime market as predatory of minority borrowers. As Gerardi, Ross and Willen (2011) note, individual households that expect increasing income and wealth over time have strong economic reasons to prefer low levels of housing equity in order to both increase current consumption and increase leverage in their investment portfolio. ${ }^{16}$ In the mortgage market specifically, Adelino, Schoar and Severino (2016) documented that the expansion of mortgage credit during the crisis was spread evenly over the entire income distribution, and that the share of mortgage dollars in

\footnotetext{
${ }^{16}$ The permanent income hypothesis implies that households will want to borrow against future labor earnings in order to smooth consumption over their lifecycle, and optimal investment theory implies that households should invest their lifetime wealth in a well-diversified portfolio, but at a young age the individuals do not have that wealth to invest and so should rationally demand high levels of leverage.
} 
delinquency attributable to low income groups actually fell during the crisis. All types of borrowers across the economy were taking advantage of relaxed underwriting standards, even if some borrowers were much more vulnerable to the financial crisis that followed.

Of course, minority borrowers were almost certainly more vulnerable to the crisis, as on average they had lower levels of wealth, more unstable employment circumstances and poorer family networks. Therefore, while not necessarily determining factors in the financial crisis, the types of product steering identified in research above and the types of loans that research suggests were eliminated by antipredatory lending policies may have been especially harmful to minority borrowers.

\section{Mortgage Servicing and Modifications}

The rapid increase in delinquencies and foreclosures during the financial crisis prompted the federal government to act to keep borrowers in their homes. Recognizing the difficulties borrowers were facing in making mortgage payments, the federal government initiated a mortgage modification program, "Making Home Affordable" or "MHA" in February 2009 as part of the Homeowner Affordability and Stability Plan. The "Home Affordable Modification Program" or "HAMP" was initiated March 4, 2009. Initial details were provided in Supplemental Directive ("SD") 09-01, issued April 6, 2009. The HAMP guidelines provided for consistency in eligibility, underwriting and servicing. There have been frequent revisions to the guidelines since that time, often detailed in supplemental directives. The HAMP program modified mortgages for borrowers with documented hardship at imminent risk of default, but who had the ability to make post-modification payments, by lowering interest rates for up to five years, extending terms and/or offering principal reductions. ${ }^{17}$ Curtailment of income, unemployment and commensurate high levels of debt pushed borrowers to request modifications. ${ }^{18}$ For minorities who might be more vulnerable to job loss and have fewer financial assets, the need for modifications might have been even more prevalent than for less vulnerable non-Hispanic white borrowers. ${ }^{19}$

There has been considerable research on the distribution of HAMP modifications and the success of the program. Goodman and Zhu (2014) examined the impact of interest rate resets on HAMP modification defaults. The HAMP program was able to reduce interest rates to as low as $2 \%$ for a period of five years. After five years, interest rates would begin to rise back to market rates, with increases of $1 \%$ per year. For borrowers who received HAMP modifications early in the program (2009-2012), resets had already occurred. Goodman and Zhu found that concerns about increased defaults due to the rate resets were overblown. They found that a 15 percent increase in defaults after large resets was an upper bound, and that many borrowers could manage the first two payment jumps well. Their research indicated the first set of substantial defaults might have occurred in 2016 (as several cohorts were reaching the third to fourth resets), with acceleration in 2017. The U.S. Department of the Treasury (Treasury) and the U.S. Department of Housing and Urban Development (HUD) produced a white paper on lessons learned from the HAMP experience. ${ }^{20}$ This paper documents that 10.5 million modification

\footnotetext{
17 The HAMP program was not designed nor intended to prevent foreclosure for all borrowers at risk of foreclosure, regardless of cause.

${ }^{18}$ See Making Home Affordable Data File, First Lien Loan Modification Data Set.

${ }^{19}$ The U.S. Treasury provided for a second lien modification program, 2MP, intended as a complementary program, which could coordinate with HAMP's first mortgage modification program to lower payments on second mortgages, see p. 192 in the HAMP handbook.

${ }^{20}$ See "Guiding Principles for the Future of Loss Mitigation."
} 
and mortgage assistance arrangements were completed between April 2009 and May 2016. ${ }^{21}$ Some of the lessons learned include providing intervention early in the default process and providing foreclosure counseling in the loss mitigation process can be helpful.

The results for loan modifications are not uniform across protected classes. A study by the Government Accountability Office $(\mathrm{GAO})^{22}$ found that for four large MHA servicers, there were statistically significant differences in the rates of denial and rates of cancellation of trial modifications for populations covered by the fair housing laws. For example, the report notes that

"for all four servicers non-Hispanic African-Americans had a statistically significant higher trial modification denial rate compared to non-Hispanic whites due to DTIs being less than 31 percent. When examining denials of trial modifications because borrowers had not provided complete information to the servicer, denial rates were significantly higher for Hispanics than for the comparison population of non-Hispanic whites for three of the four large servicers we analyzed. We also found that for all of the servicers we analyzed, non-Hispanic African-Americans had a statistically higher rate of re-default than non-Hispanic whites..."23

The California Reinvestment Coalition analyzed HAMP outcomes for California and also found that borrowers of color disproportionately faced problems accessing HAMP modifications, especially cancellation of modifications due to incomplete documentation..$^{24}$ In related research, Ferreira, Ross and Wang (2016) show that locations that experienced growth in the market penetration of high cost lenders (primarily low income and minority locations) had higher rates of foreclosure after those increases, but not higher rates of delinquency consistent with a role for servicers in the geographic concentration of foreclosures.

In brief, while efforts were made to offer substantial mortgage loan modification assistance to borrowers following the mortgage crisis, it is not clear that the outcomes were uniform with respect to borrowers from classes protected by the Fair Housing Act.

\section{E. Litigation Resulting from Alleged Violations of the Fair Housing Act}

\section{Experiences from Disparate Treatment Cases}

The Fair Housing Act (FHA) and the Equal Credit Opportunity Act (ECOA) protect consumers by prohibiting discriminatory practices, including actions that include overt discrimination, or those that result in disparate treatment or disparate impact. The FHA specifically prohibits discrimination on the basis of race or color, national origin, religion, sex, familial status or handicap. ECOA adds age and receipt of public assistance income to that list of protected classes. The regulatory agencies specify that "Illegal disparate treatment occurs when a lender bases its lending decision on one or more of the prohibited discriminatory factors covered by the fair lending laws." 25

21 Ibid., at p. 4.

22 See GAO 14-117 (2014).

23 Ibid., at p. 23.

${ }^{24}$ See California Reinvestment Coalition (2011).

${ }^{25}$ See the Office of the Comptroller of the Currency (2018). 
Throughout the past decade, there have been numerous allegations of fair lending violations filed in both private class action matters and by regulatory agencies, through the Department of Justice (DOJ). For example, DOJ settled a matter with PrimeLending in December 2010. ${ }^{26}$ DOJ alleged that Primelending engaged in a "pattern or practice of conduct in violation of the Fair Housing Act (FHA), 42 U.S.C. 3601- 3619, and the Equal Credit Opportunity Act (ECOA), 15 U.S.C. 1691 - 1691f, by charging African American borrowers higher annual percentage rates of interest for certain fixed rate loans...than charged to non-Hispanic white borrowers between 2006 and 2009." DOJ attributed these differences to a policy that allowed PrimeLending employees discretion to charge overages above par interest rates. PrimeLending denied the allegations, but agreed to pay $\$ 2$ million to resolve allegations that it charged higher prices on retail loans to African American borrowers. The Federal Trade Commission (FTC) also intervened suing Golden Empire Mortgage (GEM) and alleging that Hispanic borrowers were charged higher mortgage loan prices than similarly situated White borrowers. ${ }^{27}$ The allegations in this matter also focused on discretionary overage pricing. The case was settled in September 2010, with GEM paying $\$ 1.5$ million in damages.

The expansion of the HMDA data in 2004 to include information on whether mortgages had relatively high APRs potentially facilitated enforcement actions by non-federal entities. Several state offices of attorneys general began analyzing HMDA data for racial differences in the incidence of high cost or rate spread loans. For example, the New York Attorney General (NYAG) pursued and settled two large cases with Countrywide lending and GreenPoint Mortgage Funding in 2006 and 2007, respectively, with both cases citing racial and ethnic differences in the incidence of high cost loans, using HMDA data as an initial basis for the investigation. In the case of Countrywide, the NYAG office found unexplained racial and ethnic disparities in both prime retail and wholesale lending, but no disparities the subprime retail segment of the market. While perhaps surprising in the light of press coverage during the financial crisis, Countrywide, like many lenders with large subprime operations, had very carefully documented and closely monitored pricing policies, which likely severely limited the discretion of individual loan officers. On the other hand, loan pricing was less carefully monitored in the prime segment of the market, and both the prime retail and wholesale segments had built in pricing discretion in terms of pricing exceptions in prime retail and broker compensation in wholesale lending. Both of these factors are cited in the NYAG complaint. ${ }^{28}$ As part of the settlement in this case, Countrywide agreed to the selection of an independent consultant to monitor for a period of three years and three months Countrywide's models and methodologies with respect to pricing models. ${ }^{29}$ It is notable that in 2011 the U.S. Department of Justice (DOJ) brought and settled a very similar suit alleging pricing disparities in the prime wholesale segment of their market based on overages, underages and broker compensation disparities, again with no disparities in the retail subprime lending division. ${ }^{30}$

In the case of GreenPoint, the NYAG again identified racial and ethnic disparities in loan pricing through its wholesale channel identifying broker compensation at a key factor. The GreenPoint

${ }^{26}$ See USA v. PrimeLending (2010).

${ }^{27}$ See FTC v. Golden State Mortgage (2010).

${ }^{28}$ See NYAG v. Countrywide Home Loans, Inc. (2006).

${ }^{29}$ Regression analyses to review pricing outcomes and pricing exceptions were required the state, MSA, branch and loan officer levels. In addition, Countrywide paid $\$ 200,000$ to cover the OAG costs of investigation.

${ }^{30}$ See USA v. Countrywide Financial Corporation (2011). Similar cases were filed by U.S. DOJ against National City Bank and GFI Mortgage Bankers in 2013 and 2012, respectively. 
settlement required payments to borrowers harmed by the broker compensation system. The restitution plan was designed to compensate two types of borrowers: brokers who charged AfricanAmericans or Latinos significantly more in compensation than similarly situated whites, and brokers who had a predominantly African-American or Latino customer base and charged more in compensation than brokers with a similar, but predominantly white customer base. As noted in the settlement, high cost brokers with predominantly African-American or Latino customer bases contributed substantially to disparities in wholesale lending costs, regardless of whether or not within broker pricing differences existed at these brokers. ${ }^{31}$ In a private class action matter brought against GreenPoint Mortgage Funding, Plaintiffs alleged that "GreenPoint's credit-pricing policy authorizes loan officers, staff and brokers to impose additional discretionary financing charges and interest rate mark-ups on loans originated in the wholesale channel." 32 They claimed that due to these additional finance charges African-Americans and Hispanics who received a wholesale residential mortgage paid disproportionately higher prices than did similarly situated white borrowers. ${ }^{33}$ The case was settled after mediation on October 10,2010 , awarding $\$ 14,750,000$ for the benefit of the approximately 94,000 class members.

In a twist in the application of disparate treatment theory, homeowners in Detroit who received subprime loans filed suit against Morgan Stanley (including several corporate entities), alleging that African-American borrowers were discriminated against, based on being more likely than similarly situated non-Hispanic white borrowers to receive "combined-risk" loans. ${ }^{34}$ The Plaintiffs defined the high risk loans as: "loans that meet the definition of high-cost loan under [the] HMDA and also contain two or more of the following high-risk terms: (a) the loan was issued based upon the "stated income," rather than the verified income, of the borrower; (b) the debt-to-income ratio exceeds $55 \%$; (c) the loanto-value ratio is at least $90 \%$; (d) the loan has an adjustable interest rate; (e) the loan has "interest only" payment features; ( $f$ ) the loan has negative loan amortization features; (g) the loan has "balloon" payment features; and/or (h) the loan imposes prepayment penalties." ${ }^{35}$ In this matter, the Court did not certify the class and no further action resulted.

In summary, lenders have regularly settled disparate treatment cases in instances where substantial pricing disparities have arisen from lenders allowing loan officers and mortgage brokers discretion is setting prices. To our knowledge, such cases have typically not uncovered pricing differentials in the retail subprime market where loan officers tend to have much less discretion over pricing. Further, attempts to classify as discriminatory certain types of products, such as those typically found in the subprime sector, have not generally succeeded in court.

${ }^{31}$ See NYAG v. GreenPoint Mortgage Funding, Inc. (2007).

32 See Ana Ramirez, Ismael Ramirez and Jorge Salazar, on behalf of themselves and all others similarly situated, Plaintiffs v. GreenPoint Mortgage Funding, Inc., Defendants, United States District Court for the Northern District of California; 08-cv-00369-THE, 2010.

${ }^{33}$ See Stipulation and Agreement of Settlement in the GreenPoint Mortgage Funding Matter, October 29, 2010, available at: https://www.clearinghouse.net/chDocs/public/FH-CA-0011-0008.pdf, last accessed July 23, 2018.

${ }^{34}$ See Adkins v. Morgan Stanley, U.S.D.C., Southern District of NY, 12-cv-7667 (VEC), May 13, 2015.

${ }^{35}$ See https://casetext.com/case/adkins-v-morgan-stanley-morgan-stanley-co. 


\section{Disparate Impact Cases}

Until recently, there were few disparate impact cases brought under the FHA with respect to mortgage lending. However, the recent finding in the "Inclusive Communities" case has led to an increase in such cases, with disparate impact cases becoming the subject of much deliberation over the past few years. The OCC defines disparate impact as "A lender's policies, even when applied equally to all its credit applicants, may have a negative effect on certain applicants." ${ }^{36}$

The U.S Supreme Count confirmed in Texas Department of Housing and Community Affairs v. The Inclusive Communities Project, Inc. ("Inclusive Communities") that disparate impact claims are cognizable under the Fair Housing Act. ${ }^{37}$ This followed the decisions by many federal appellate courts recognizing FHA claims for disparate impact. The ruling included considerable discussion on the limitations of disparate impact liability. ${ }^{38}$ Much research has followed that finding, including a review by Schwemm (2018). Schwemm opines that Justice Kennedy, in casting the deciding vote (5-4 outcome) expansively read the FHA "to help accomplish its goal of replacing a residentially segregated society with a more integrated one." 39 Among other "cautionary standards" the Court articulated was that the plaintiff had the burden of proof with respect to proving a "robust" causal connection between the defendant's practice and any statistical disparities." ${ }^{0}$ Inclusive Communities required the plaintiff to show not only a disparate impact on a protected class, but also that the defendant could have achieved the outcome with a less discriminatory alternative (LDA). ${ }^{41}$

Shortly before the Inclusive Communities case was resolved by the Supreme Court, HUD promulgated a disparate impact regulation in 2013. ${ }^{42}$ This regulation updated the standards HUD set for the determination of disparate impact. In its update of 24 CFR, Part 100, Subpart G, $\S 100.500$ it stated that ${ }^{43}$ "Liability may be established under the Fair Housing Act based on a practice's discriminatory effect." The practice has a discriminatory effect where it "actually or predictably results in a disparate impact on a group of persons or creates, increases, reinforces, or perpetuates segregated housing patterns because of race, color, religion, sex, handicap, familial status, or national origin." The initial burden of proof falls on the plaintiff in proving that a challenged practice caused or predictably will cause a discriminatory effect. If so, the defendant has the burden of proving that the challenged practice is necessary to achieve one or more substantial, legitimate, nondiscriminatory interests of the respondent or defendant (business necessity). If the defendant satisfies the burden of proof as to the legitimate interest, the plaintiff may still prevail "upon proving that the substantial, legitimate,

${ }^{36}$ Op. Cit., OCC (2018) Fair Lending.

${ }^{37}$ The decision in Texas Department of Housing \& Community Affairs v. Inclusive Communities Project, Inc, 135 S. Ct. 2507 (2015) came on June 25, 2015.

${ }^{38}$ See, for one example, Glassman and Verna (2016). The legal questions surrounding the application of disparate impact theory to mortgage lending are much too complex to address fully in this article.

${ }^{39}$ Schwemm (2015) at p. 4. Daniel Sheehan (2017) argues that while the finding affirms that the FHA encompasses disparate impact liability, the framework established by Justice Kennedy will require a tradeoff between integration and revitalization that is likely to favor revitalization of communities over integration, p. 392.

40 lbid., at p. 5.

${ }^{41}$ Also see Sheehan (2017) and Callison (2017) in the Journal of Affordable Housing.

${ }^{42}$ HUD had responsibility for FHA delegated to it by 42 U.S.C. $§ 3608$ (a). In 2013, HUD issued a new standard for matters involving disparate impact. This is often referred to as the HUD Effects Standard.

43 Ibid., at 11482. 
nondiscriminatory interests supporting the challenged practice could be served by another practice that has a less discriminatory effect."

In recent years, the U.S. DOJ has brought and settled two major cases disparate impact cases against Wells Fargo and Countrywide where a substantial component of the complaint arose from the differential placement of minority borrowers into subprime loan products. The DOJ suits alleged that both Wells Fargo and Countrywide set up a broker compensation system that encouraged brokers to place prime qualified borrowers into subprime loans that tended to be both higher cost and more likely to include pre-payment penalties, and that this system had a disparate impact on prime qualified minority borrowers causing them to be significantly more likely to be placed into subprime products than equivalent white borrowers. ${ }^{44}$ The Wells Fargo suit went further than the Countrywide suit alleging a disparate impact in the retail lending segment of the market. This aspect of the complaint is especially notable because the complaint acknowledged that prime and subprime loan officers were organizationally distinct and did not have the ability to issue loan products from the other market segment. The complaint does not mention any racial or ethnic disparities in the retail price of prime or subprime credit or any disparities in the likelihood of referral up to prime to down to subprime. Rather, the complaint hinges on the failure of Countywide loan officers to reliably and comprehensively refer prime qualified borrowers to the prime lending operation, instead placed prime qualified borrowers in subprime products that on average implied a much higher cost of credit. When combined with a disproportionate number of minority applicants at Wells Fargo's subprime offices, this failure had an alleged disparate impact on minority borrowers. The complaint documented both alleged employee manipulation of the referral monitoring systems and management disregard of such manipulation. ${ }^{45}$ Interestingly, the complaint never discusses the potential causes of the disproportionate representation of minorities at the subprime offices, and it is an unanswered question of whether office location decisions or marketing practices may have had a disparate impact on minority borrowers. ${ }^{46}$

In addition, a recent set of disparate impact class actions involved municipalities or other jurisdictions bringing suits against lenders for the impact on their communities of increased mortgage defaults and foreclosures. The cities or counties involved included Los Angeles, Miami, Miami Beach, Cook County, Philadelphia and others. One of these cases, Bank of America, et al. v. City of Miami, 581 U.S. was decided by the U.S. Supreme Court found that Miami's claims did not satisfy the FHA's "zone of interests" and "proximate cause" requirements, vacating the earlier $11^{\text {th }}$ Circuit ruling in favor of Miami. Essentially, the alleged harm was considered "too remote" from the unlawful conduct. The plaintiffs had claimed that the mortgage lending activities of the defendants led to "concentrated foreclosures" in minority neighborhoods, which hurt efforts to create "stable integrated neighborhoods," which in turn led to diminished tax revenues and increased demand for municipal or county services. The Court ruled that FHA violations require a direct relation between the injury claimed by the plaintiffs and the conduct of the defendants. In City of Los Angeles v. Bank of America Corp, the $9^{\text {th }}$ Circuit Court ruled in favor of

${ }^{44}$ See USA DOJ v. Countrywide (2011) and USA v. Wells Fargo (2012).

45 The complaint emphasizes Wells Fargo's failure to adequately implement and monitor the "A-paper Filter" and "Enhanced Care Filter" programs, which were to assure that prime eligible borrowers were referred to the bank's prime division.

${ }^{46}$ In a complaint against GFI Mortgage Bankers mentioned earlier, the DOJ also describes loan officer and broker compensation systems as having a disparate impact, but that complaint focused on disparities in overages and underages, and broker compensation, similar to other disparate treatment complaints. See USA DOJ v. GFI (2012). 
Bank of America at summary judgment, finding that there was no evidence of any actionable FHA violation during the two year statute of limitations period. A similar case in Los Angeles, versus Wells Fargo \& Co., was appealed to the $9^{\text {th }}$ Circuit.

The Supreme Court's Inclusive Communities ruling on disparate impact has opened the doors for new litigation against mortgage lenders. However, there are clear limits to how far the courts will go in establishing both standing and liability. Just as the courts rejected efforts to broadly label high cost loans with specific risky features as discriminatory, the courts have failed to award standing to cities and counties seeking damages for high and concentrated foreclosure rates within their borders. Several suits have led to large settlements based on links between the cost of credit and loan officer and broker compensation, and in the wake of "Inclusive Communities" settlements arose from differential compensation between prime and subprime products. However, the Wells Fargo retail lending complaint stands out among these disparate impact cases. The complaint arises from a failure to refer sufficient borrowers up to the prime subsidiary, as opposed to steering borrowers into subprime products. Recent HUD regulation and Justice Kennedy's ruling both emphasize identification of specific business practices, and courts have historically set the scope of business practices rather narrowly.

\section{F. Changes in the Regulatory Process: Dodd Frank and CFPB}

In implementing the Dodd-Frank Act, the Consumer Finance Protection Bureau (now BCFP) issued several key rules governing the mortgage lending process that are meant to improve the consumer's ability to obtain a fair and understandable mortgage. These rules include The Truth in Lending Act (TILA)/Real Estate Settlement Procedures Act (RESPA) Integrated Disclosure Rule (known as TRID), the Ability to Pay (ATR) and Qualified Mortgage Standards (QM) Rules, the Loan Originator Compensation Requirements and timely notification requirements in loss mitigation and error resolution procedures.

TRID combines the disclosure requirements under TILA and RESPA simplifying the forms and attempting to make the information more accessible to the general public. Lenders are now required to provide cost estimates three days after application, and final closing disclosures three days before closing. We cannot overstate the importance of clear, consistent information on the cost of credit that is provided in a timely manner so that all borrowers, including those in protected classes, understand the true cost of their mortgage prior to their closing.

Further, there are limits on closing cost and interest rate increases after the final closing disclosure. Anecdotally, in past years we had observed instances where brokers dramatically increased the final note rate at closing claiming that they were not able to get the original promised loan. In some cases, the original lender confirmed that the wholesale rate provided to the broker never changed. If a broker knows that the borrower is desperate to close the loan, a hold-up situation is created where the broker can extract substantial surplus because the borrower cannot commit to walk away. This new federal policy makes the commitment for the borrower by requiring a new three day waiting period when costs increase substantially.

The new ATR Rules require lenders to make a good faith effort to confirm the borrower's ability to repay the loan. Government guaranteed (FHA/VA) loans or loans purchased by the Government Sponsored Enterprises (GSEs), Fannie Mae and Freddie Mac, are presumed to satisfy the ATR requirements. Therefore, in the current market, the ATR requirements primarily apply to the jumbo market, but could be relevant more broadly in the future if a substantial non-jumbo, privately 
securitized market were to re-emerge. For non-agency loans, the rule establishes criteria for Qualifying Mortgages (QM) that are presumed to satisfy ATR. The QM standards prohibit no or low documentation loans, interest only loans, negative amortization loans, loans with balloon payments, pre-payment penalties on adjustable rates mortgages unless an alternative product without pre-payment penalties is offered, and limits points and fees (excluding discount points) at $3 \%$ of the loan amount. Finally, the total DTI ratio of the borrower is limited to $43 \%$ of gross income. The broad requirement to make a "good faith effort" appears to have led to lenders putting a high premium on meeting the QM standard. DeFusco, Johnson, and Mondragon (2017) document a dramatic decline in the number of jumbo loans issued with $44-45 \%$ DTI ratios when the ATR/QM requirements were imposed.

The limit on DTI ratios may have unintended consequences. First, DTIs have historically been quite weak predictors of default or foreclosure risk. Households, including minority and low income households, may differ in their ability to manage debt loads in ways that are difficult for lenders to determine. Second, income shocks are often large due to job loss so that a substantial difference in DTI, e.g. $38 \%$ and $45 \%$, is relatively unimportant when household income falls by $35 \%$, increasing those two ratios to $58 \%$ and $69 \%$, respectively. ${ }^{47}$ Job loss and income shocks also may differentially impact minority households due to differences in financial resources. Second, a DTI requirement that is constant across housing markets makes little sense. In high housing cost markets, individuals earn a significant wage premium. Since the prices of most other necessities vary much less across markets, households in a high cost markets can afford to devote a larger share of income to housing. In this situation, looking at residual income levels may make more sense than a strict DTI ratio.

The DTI limit also requires that adjustable rate mortgages (ARMs) be evaluated at the fully indexed rate. This rule does address concerns about loans with teaser rates and rapid rate resets. However, adjustable rate mortgages have traditionally been a reasonable and safe strategy for increasing affordability by lowering interest rates and so can increase minority access to homeownership. This rule essentially prohibits that strategy because any savings in housing expenses are completely undone by evaluating the mortgage under a worst-case scenario. We agree that ARM borrowers need some DTI cushion in case rates increase, but fully indexing is too extreme.

The QM requirement for an alternative non-prepayment penalty product for ARMs can also increase the transparency of mortgage pricing. Pre-payment penalties when combined with relatively rapid rate resets and the typically rapid pre-payment of subprime loan products can represent a reliable source of income, replacing income that might otherwise have been raised by closing costs or note rates. When used this way, pre-payment penalties could obscure the full cost of credit. Similar to TRID, we believe that credit markets will operate better when the total cost of credit is documented in a simple and transparent manner prior to the closing. The regulation puts no restrictions on pre-payment penalties for fixed rate mortgages where payment shock is eliminated. In fact, pre-payment penalties should provide the largest savings for borrowers and so increase affordability the most for fixed rate loans because they reduce the risk faced by lenders when interest rates fall. ${ }^{48}$

\footnotetext{
47 The growing importance of part time work, contingent employment and the "gig" economy may increasingly lead to less discrete and more frequent income shocks, raising the importance of debt to income ratios.

${ }^{48}$ Similarly, Freddie Mac and Fannie Mae might increase affordability by increasing the three year time limit on pre-payment penalties for fixed rate mortgages.
} 
Finally, the loan originator compensation rule (2011) prohibits both direct or indirect links between loan officer or mortgage broker compensation and any of the mortgage transaction's terms or conditions. The rule explicitly prohibits basing compensation on proxies that correlate with the cost of credit or specific loan terms. The rule also bars "dual compensation" where the agent is both directly compensated by the consumer and receives payments from the lender. The purpose of this rule is to eliminate the incentive that loan officers and brokers had to charge consumers above market prices or to steer consumers towards higher compensation products (sometimes riskier products). This rule is motivated in part by providing protection to borrowers who may lack financial sophistication and so either fail to shop for or to accurately assess the cost of credit. Alexandrov and Nikolayev (2018) argue that approximately half of borrowers obtained only one quote for their mortgage, and that most consumers dramatically underestimate price dispersion in the mortgage market.

One clear concern in terms of access to credit is the continued low level of wholesale lending in the post-crisis period. Broker originations fell by 75\% between 2007 and 2010, while retail and correspondent lending fell by only $24 \%$ and $13 \%$, respectively (Courchane et al. 2012). Clearly, the collapse of wholesale lending preceded the compensation rule, issued in 2013 , but it may have slowed the recovery of this segment of the market.

\section{G. Fair Lending within the FinTech World ${ }^{49}$}

While we have documented many of the changes in mortgage markets over the decades since passage of the Fair Housing Act, the world for lending is changing rapidly. In just the past few years, FinTech firms have emerged, offering the promise of broader access to credit for consumers and businesses with reduced cost and more competition. However, the use of new technology, new data sources and alternative credit modeling methods also poses potential for fair lending risk - notwithstanding the fair lending benefits of reduced discretion from automated decision-making. The federal financial regulatory agencies appear to be adopting a fairly constructive and balanced approach to FinTech. The OCC, FDIC, Consumer Financial Protection Bureau (Bureau) and FTC have each published reports on FinTech related topics, including machine learning and alternative data, that have recognized both the potential benefits and risks. ${ }^{50}$

FinTech lenders are primarily technology-focused online lending platforms which typically access capital from sources other than traditional depository institutions. FinTech lenders leverage new technology to compete directly with higher-cost and less convenient traditional lenders and provide opportunities for capital in search of higher returns in a low interest rate environment. They may offer more flexible and innovative products, more favorable pricing to consumers, quicker decisions and more efficient service. Some typical distinguishing characteristics of FinTech lenders are online applications and originations; a high degree of automation; proprietary and innovative predictive models for credit scoring, fraud detection and pricing; the use of non-traditional data; and a rapid pace of model adaptation. Recently, equity and debt financing, direct bank funding and securitization have played an increasing role in funding FinTech lending. While these lenders tend to compete against banks, many financial institutions are also partnering with or investing in these new lenders.

\footnotetext{
${ }^{49}$ See Courchane and Skanderson (2017), from which this section is drawn.

${ }^{50}$ See Evans (2017). Also see recent working papers on FinTech by Jagtiani and Lemieux (2018a 2018b).
} 
Many FinTech lenders have focused on markets historically overlooked by banks competing with higher-priced finance companies and payday lenders. Some lenders have focused on refinancing and consolidating higher-interest-rate debt to lower rates, including student loans and credit card debt. To some extent, all have focused on using cutting-edge technology to identify and acquire creditworthy consumers and to originate loans at low cost, as have technology "disrupters" in other industries. While they still rely heavily on traditional direct mail marketing and advertising media, they also mine social media, online ad placement and lead generators for prospects. The progress of FinTech lending in the mortgage space has been much slower, but some mortgage lenders, e.g. Rocket loans, are similar to other FinTech lenders. SoFi also provides loans in the mortgage area.

Lenders in the FinTech world often collect and combine large amounts of data about potential borrowers from many diverse data sources - well beyond the three national credit reporting agencies and use computationally intensive processes to discover patterns and interrelationships in the data that help to understand borrower habits and predict credit behavior. These data sources may include spending and shopping behavior, bank account activity, sources of credit used, data from alternative credit reporting agencies, online and social media activity, among other sources. Nonetheless, many rely on traditional credit bureau scores (such as FICO and Vantage scores) and ability to repay (ATR) measures (such as DTI ratios or residual income measures); while others use a combination of traditional and non-traditional credit history, behavioral and other attributes; and still others exclusively use proprietary credit models and decision systems. Some use no credit score information at all.

Consumer advocates have long argued that credit repository data should be supplemented with other information on the ability to manage credit such as utility account information and payments, and rental payments, among others. The FinTech lenders often use similar information to both underwrite and price credit. While these practices may in principle help minority borrowers with thin credit profiles, they also have raised some concerns about whether the systems used to collect such information may be racially biased, e.g. "racist algorithms" present in internet search engines.

\section{The role of machine learning}

FinTech lenders may adopt complex new "machine learning" models to augmenting or replace traditional credit scoring methods. Machine learning uses computers to create analytical models on an automated basis, and to make decisions without being programmed with a specific set of decision criteria. Based on the available data, general model structure and business objectives defined by the model developer, a computer determines which data elements to use in predicting credit behavior and which consumers to solicit or applicants to approve. Familiar everyday examples of machine learning from outside of the financial world are the highly personalized advertising on Facebook and product recommendations on Amazon.

Traditionally, credit scoring uses statistical analysis to derive a fixed formula based on a defined set of credit history attributes, each of which is assigned a fixed number of points resulting in a numeric credit score. Scoring models are usually adjusted or replaced over time as predictive performance degrades, but usually no more often than annually. By contrast, machine learning models are flexible algorithms that grow and change with exposure to new data. Such modeling methods can be adept at crunching through large volumes of data to identify characteristics and their interrelationships that help to predict credit behavior. Machine learning methods allow the model to build and update itself. The automated model determines which variables are useful and how to combine them to best predict 
behavior based on the latest data available. The model determines which applicants should be approved based on targets for business objectives (e.g., charge-off rates or profitability), without necessarily computing a numeric credit score. In some cases, machine learning may combine the results of multiple models to increase predictive power. Finally, machine learning methods tend to select attributes and combinations of attributes based purely on the strength of their correlations to credit outcomes. Less emphasis is placed on whether there are logical economic or behavioral reasons underlying those correlations.

A key motivation for machine learning is the desire to identify and exploit subtle and difficult to observe relationships among disparate data elements from many different sources that can be combined to better predict consumer behavior. As a simple example, there may be a distinct difference in default risk between a consumer with multiple recent delinquencies on a single credit account and several recent credit card inquiries who has also recently applied for a payday loan, compared to a consumer who is otherwise the same but has delinquencies across multiple accounts. It would be prohibitively time consuming or impossible for a human analyst to evaluate all possible interrelationships among all available data elements to identify the characteristics that best predict default. Machine learning techniques, however, can allow an analyst to consider an arbitrary number of complex interrelationships among hundreds or thousands of variables. Further, because the process is automated, it can be updated frequently as new data becomes available, which is especially valuable for new products and new lenders with limited loan performance experience.

\section{Fair lending benefits and risks}

The use of alternative modeling approaches, augmented with a broader set of data elements, has the potential to broaden credit access for consumers. ${ }^{51}$ Using alternative data sources and modeling methods, lenders could better serve consumer segments that historically have been underserved, such as consumers who are unbanked, have low or moderate incomes, do not use traditional credit products, are self-employed or have little established credit history. For example, a 2015 study (Breevoort, Grimm and Kambara 2015) by Bureau staff estimated that about $15 \%$ of Blacks and Hispanics are "credit invisible" - meaning that they have no records at the national credit reporting bureaus - compared to about $9 \%$ of Whites and Asians. ${ }^{52}$ The study also found that a further $13 \%$ of Blacks and $12 \%$ of Hispanics have credit bureau records that cannot be assigned a traditional credit score because of insufficient credit activity or history, compared to about $7 \%$ of Whites and Asians. The results suggest that mining alternative data sources for information about consumer payment behavior or risk characteristics could potentially broaden access to credit for minority consumers.

Further, the automation of credit application and decision processes reduces the risk of disparate treatment on a prohibited basis that can arise in manual or judgment based decisions. Given the history of legal settlements that regularly focus on discretion provided to loan officers or mortgage brokers and empirical evidence of low levels of discrimination when discretion is limited, the gains for minority borrowers from expanded use of automated systems could be substantial.

\footnotetext{
${ }^{51}$ See the FTC (2016).

52 Brevoort et al. (2015).
} 
However, fair lending risk can still arise with automated and machine learning processes and fair lending risk management becomes more challenging with machine learning and data analytics. There are various potential sources of fair lending risk that should be considered in the use of alternative data and automated decision processes. The full credit lifecycle must be evaluated for fair lending risk, including marketing, underwriting, fraud risk detection, setting terms and conditions (pricing, credit line/limit determination, etc.), servicing and collections. Each of these stages in the process may involve different data sources, decision criteria and models with different fair lending risk potential, and each should be evaluated.

The risk of a disparate impact on a prohibited basis should also be evaluated. Ostensibly neutral variables that predict credit behavior may nevertheless present disparate impact risk if they are so highly correlated with a legally protected characteristic that they effectively act as a substitute for that characteristic. Some alternative data elements that may be used in credit models and decisions have well recognized correlations with prohibited factors, posing disparate impact risk. For example, geographic location, use of banking services, educational attainment, college or university attended and use of nonprime credit tend to be correlated with race and ethnicity. Unlike credit history data, which has long been accepted by regulatory agencies as having a legitimate business justification notwithstanding its correlations with prohibited bases, alternative credit attributes have yet to gain widespread acceptance and some are viewed with suspicion. If such factors are used in credit decisions, lenders should be diligent in developing rigorous evidence of their business justification and in evaluating them for potential fair lending impacts.

In fact, even without individual variables that are highly correlated with protected class, machine learning algorithms could be very effective in capturing traditionally unexplained racial and ethnic differences in loan performance. As Ross and Yinger (2002) note, predictive models that omit a trait, such as race or ethnicity, will yield biased coefficients on legitimate risk variables that correlate with those traits in order to obtain the best prediction, effectively proxying for the omitted trait. Machine learning models could dramatically exacerbate this problem by agnostically exploring the inclusion of hundred or even thousands of potential variables whether or not the variables actually contribute to delinquency or default. Such models could effectively proxy for race in very complex ways that would be difficult to detect.

Predictive variables based on aggregated information should be given particular attention. For example, the average credit risk of people residing in a given geographic area, local economic factors (e.g., local unemployment rates or property appreciation rates), or indicators of a consumer's memberships or affiliations can pose a fair lending risk because they tend to treat large groups of consumers similarly regardless of their individual risk characteristics and because the aggregated factors may be correlated with one or more prohibited bases. For example, a geographically based predictive variable would treat high-risk and low-risk consumer within a given geographic area as having the same risk (other things equal). If geographic location is correlated with race or ethnicity, then the geographically based variable may end up having an unjustifiable disparate impact even though it appears to help predict credit risk on average.

The use of alternative data sources and machine learning methods can also create or perpetuate biases if there are biases inherent in the data sources themselves. If data sources used are not representative of the population of consumers potentially qualified for the credit product of interest 
and/or systematically exclude certain segments of the population, they may tend to create feedback loops that perpetuate or reinforce historical biases. For example, reliance on data about banking behavior could tend to underrepresent certain minority groups, and reliance on data about social media or online shopping behavior could tend to underrepresent certain age groups.

Attention also should be given to the potential risk of redlining, reverse redlining or predatory lending. Such risks could arise from targeting credit products to such niche markets as higher-income or higher credit quality consumers, lower-income or nonprime consumers, consumers who are internetsavvy and communicate heavily through social media, or consumers who have a large "data footprint." As was seen with the growth of the subprime sector, segmentation of markets can be especially harmful to minority borrowers even in an environment where decision making systems are race neutral.

\section{H. Discusssion}

The empirical evidence is clear that unexplained racial and ethnic differences in both mortgage underwriting and prices are relatively small when looking within lender and controlling for product attributes. Yet, race and ethnicity appear to play a role in determining mortgage market outcomes in the U.S. economy. We believe many factors, including information, attachment to financial markets, preapplication assistance levels and even shopping behavior contributed to the long-standing failure of prime qualified minority borrowers to access the conventional, conforming loan market. Historically, the cost of this failure was likely modest and reflected in the disproportionate share of minorities in the somewhat more expensive FHA mortgage products. However, over the decade preceding the financial crisis, the growing subprime mortgage market dramatically eroded FHA's market share, and minority buyers may have received higher cost and riskier products than they might have otherwise chosen. The DOJ case against Wells Fargo's retail lending is illustrative of this, alleging a disproportionately large number of minorities in subprime loans, while failing to provide any evidence of disparate treatment in prime loan approvals or referrals between prime and subprime loan offices.

The evidence also suggests that loan officer and mortgage broker discretion, especially when combined with historical compensation systems, played a substantial role in creating the racial differences that are observed market wide. Racial and ethnic differences in prime mortgage underwriting across lenders seem to be explained because minority borrowers' applications do not match the critieria used by individual lenders, and testing evidence suggests that loan officers, who should know the lender's standards, may provide less assistance and information to minority borrowers. To our knowledge, disparate treatment cases on mortgage pricing have tended to focus on retail prime lending and wholesale lending, rather than on retail subprime lending where loan officers typically had much less discretion to set prices. Further, the vast majority of the pricing differences appear to arise between the prime and subprime sectors based on product attributes. Therefore, placement in subprime products is typically a more important factor for the cost of credit than individual discretion on pricing, and several important legal cases point to mortgage broker discretion as a reason behind the disproportionate representation of minorities in subprime products. While we view the expansion of subprime credit as driven heavily by borrower demand (especially among middle and high income borrowers who had substantial attachment to the banking system), individual loan officers and mortgage brokers still faced substantial incentives to place less informed borrowers into these riskier products. Therefore, the barriers that minorities faced in the prime mortgage market likely increased their exposure to subprime lending. 
In this context, we believe that the consumer protection provisions adopted by the CFPB under Dodd-Frank are important for reducing market wide differences in mortgage market outcomes. The improved disclosure of the cost of credit, the prohibition on large changes in costs immediately prior to closing, the requirements for Qualifying Mortgages, and the restrictions on loan officer and broker compensation all targeted various issues that were observed in the subprime sector. Further, the broker compensation rules were clearly designed to rule out the types of compensations system that led to virtually all of the major disparate treatment and disparate impact settlements. Minority borrowers were likely more at risk from the types of behaviors these regulations address because they are less attached to traditional financial institutions, are less likely to shop for a mortgage, and are residentially concentrated in lower income neighborhoods.

Therefore, when considering suggestions to liberalize markets in order to increase access to credit, policymakers must remember lessons learned in the aftermath of the crisis. Accurate information on the cost of credit is critical, and complex products that generate revenue beyond closing costs, interest rates and servicing likely put borrowers at risk, especially minority borrowers. Discretion often puts minority borrowers at a disadvantage in the mortgage market, even if in principle discretion allows lenders to offset criteria like credit score where on average minorities perform poorly. Segmentation of financial markets can be especially harmful to minorities because often those groups are less attached to financial institutions, as suggested by the lending patterns preceding the crisis. In the context of recent CFPB regulations, retaining the protections under the TILA/RESPA Integrated Disclosure Rule and the Loan Originator Compensation Rule would appear to be very important. However, liberalization of the DTI requirements for Qualifying Mortgages, increased use of pre-payment penalties on fixed rate mortgages, and more allowance for higher broker compensation for smaller mortgages and in thinner markets are all examples of reforms that might increase minority access to credit.

Further, FinTech could substantially increase opportunities for individuals and groups with traditionally lower access to traditional financial markets. FinTech could reduce the cost of obtaining information, lead to increased competition and eliminate discretion, reducing discrimination arising from interpersonal interactions. Imagine a scenario where an artificial intelligence programs first questions a borrower on their financial characteristics, housing preferences, household budget, future financial plans and willingness to accept risk, then identifies the lenders most likely to provide credit at favorable terms, and prepares mortgage applications for each lender using information on past submissions to and responses from that lender. While we understand the concerns about disparate impact from automated decision making models within the FinTech world, we are far more excited about the increased opportunities that automated systems could provide to minority borrowers. To us, the most significant concern arising from FinTech is the segmentation of markets that could occur based on profit driven, sophisticated marketing and product placement, not unlike how Amazon, Facebook or Google tailor individual specific on-line advertisements. Minority borrowers faced a very high cost during the financial crisis from segmentation of the mortgage market into prime and subprime sectors, and the growth of FinTech could present similar risks. 


\section{REFERENCES}

Adelino, M. A. Schoar and F. Severino (2016). "Loan originations and defaults in the mortgage crisis: The role of the middle class," Review of Financial Studies 29:7, 1635-1670, https://dspace.mit.edu/handle/1721.1/109226.

Agarwal, S., G. Amromin, I. Ben-David, and D. Evanoff (2016). "Loan product steering in mortgage markets," NBER Working Paper \#22696, https://papers.ssrn.com/sol3/papers.cfm?abstract id=2846932.

Agarwal, S., G. Amromin, I. Ben-David, S. Chomsisengphet, and D. Evanoff (2014). "Predatory lending and the subprime Crisis," Journal of Financial Economics, 113, 29-52, http://www.ushakrisna.com/2401.pdf.

Alexandrov, Alexei and Sergei Nikolaye (2018). "No shopping in the U.S. mortgage market: direct and strategic effects of providing information," Consumer Financial Protection Bureau, Office of Research, Working Paper No. 2017-01, May 15, https://www.consumerfinance.gov/dataresearch/research-reports/know-before-you-owe-mortgage-shopping-study.

Avery, Robert B., Patricia E. Beeson, and Mark S. Sniderman (1996). "Neighborhood information and home mortgage lending," Federal Reserve Bank of Cleveland, Working Paper 96-20, https://www.clevelandfed.org/newsroom-and-events/publications/working-papers/workingpapers-archives/1996-working-papers/wp-9620-neighborhood-information-and-home-mortgagelending.aspx.

Avery R., G. Canner, and R. Cook (2005). "New information reported under HMDA and its application in fair lending enforcement," Federal Reserve Bulletin, Summer, 344-94.

Bayer P., F. Ferreira, and S. Ross (2016). "The vulnerability of minority homeowners in the housing boom and bust, American Economic Journal: Economic Policy, 8:1-27, https://repository.upenn.edu/realestate papers/28/.

Bayer P., F. Ferreira, and S. Ross (2018). "What drives racial and ethnic differences in high cost mortgages? The role of high risk lenders," Review of Financial Studies, 31:1, 175-20, https://www.researchgate.net/publication/323548673 What Drives Racial and Ethnic Differenc es in High-Cost Mortgages The Role of High-Risk Lenders.

Been, Vicki, Sewin Chan, Ingrid Gould Ellen, and Josiah R. Madar (2011). "Decoding the foreclosure crisis: causes, responses, and Consequences, Journal of Policy, Analysis and Management: PointCounterpoint, 30, 388-396, https://onlinelibrary.wiley.com/doi/abs/10.1002/pam.20570.

Bhutta, N., and D. Ringo (2014). "The 2013 home mortgage disclosure act data," Federal Reserve Bulletin, 100, 1-37, https://www.federalreserve.gov/pubs/bulletin/2015/pdf/2014 HMDA.pdf.

Blackburn, McKinley, and Todd Vermilyea (2004). "Racial disparities in bank-specific mortgage lending models, Economics Letters, 85, 379-383,

https://www.sciencedirect.com/science/article/pii/S0165176504002198.

Bocian D., K. Ernst, and W. Li (2008), "Race, ethnicity and subprime home loan pricing," Journal of Economics and Business, 60, 110-24, https://www.sciencedirect.com/science/article/pii/S0148619507000847.

Bocian, D., W. Li and K. Ernst (2010). "Foreclosures by race and ethnicity: The demographics of a crisis," Center for Responsible Lending, Research Report, https://www.responsiblelending.org/mortgagelending/research-analysis/foreclosures-by-race-and-ethnicity.pdf. 
Bostic. R., K. Engel, P. McCoy, A. Pennington-Cross, and S. Wachter (2008). "State and local antipredatory lending laws: The effect of legal enforcement mechanisms," Journal of Economics and Business, 60: 47-66, https://fcic-static.law.stanford.edu/cdn media/fcic-docs/2008-0200\%20State\%20and\%20Local\%20anti-predator\%20lending\%20laws.pdf.

Brevoort, Kenneth P., Philip Grimm, and Michelle Kambara (2015). "Data point: credit invisibles," Consumer Financial Protection Bureau, Office of Research, May 2015, http://files.consumerfinance.gov/f/201505 cfpb data-point-credit-invisibles.pdf.

Browne, Lynne and Geoffrey M.B. Tootell (1995). "Mortgage lending in Boston: A response to the critics," New England Economic Review, Sept/Oct. 53-78, https://www.bostonfed.org/publications/new-england-economic-review/1995-issues/issueseptember-october-1995/mortgage-lending-in-boston-a-response-to-the-critics.aspx.

Calem, P. S., K. Gillen and S. Wachter (2004). "The neighborhood distribution of subprime mortgage lending," Journal of Real Estate Finance and Economics, 29: 393-410, at: http://realestate.wharton.upenn.edu/wp-content/uploads/2017/03/404.pdf.

Calem, Paul S., Jonathan E. Hershaff, Susan M. Wachter (2004). "Neighborhood patterns of subprime lending: Evidence from disparate cities" Housing Policy Debate, 15:3, 603-622, https://www.tandfonline.com/action/doSearch?target=default\&ContribAuthorStored=Calem, Paul S.

California Reinvestment Coalition (2011). Race to the bottom: An analysis of HAMP loan modification outcomes by race and ethnicity for California, July, http://www.calreinvest.org/news/race-to-thebottom-an-analysis-of-hamp-loan-modification-outcomes-by-race-and-ethnicity-for-california.

Callison, J. William (2017). "Inclusive Communities: Geographic desegregation, urban revitalization and disparate impact under the fair housing act, Journal of Affordable Housing, 25:3, 421-434.

Chan, Sewin, M. Gedal, V. Been, and A Haughwout (2013). "The role of neighborhood characteristics in mortgage default risk: Evidence from New York City," Journal of Housing Economics, 22, 100-118, https://nyuscholars.nyu.edu/en/publications/the-role-of-neighborhood-characteristics-inmortgage-default-risk.

Chan S., A. Haughwout, and J. Tracy (2015). "How mortgage finance affects the urban landscape," Handbook of Urban and Regional Economics, 5A, Eds. G. Duranton, V. Henderson, and W. Strange, 987-1045, Amsterdam, North Holland, http://real.wharton.upenn.edu/ duranton/Duranton Papers/Handbook/How mortgage finance affects the urban landscape.pdf.

Courchane, M. (2007). "The pricing of home mortgage loans to minority borrowers: How much of the APR differential can we explain?" Journal of Real Estate Research, 29:4, 399-439, http://pages.jh.edu/jrer/papers/pdf/past/vol29n04/04.399 440.pdf.

Courchane, Marsha J., Rajeev Darolia and Peter M. Zorn (2012). "Broker compensation patterns and trends: 2005-2009," Atlantic Economic Journal 40, 229-251.

Courchane, Marsha J. and David Skanderson (2017). "Fair lending in the brave new world of big data," Charles River Associates, Washington DC.

DeFusco, A., S. Johnson, and J. Mondragon (2017). "Regulating household leverage," Northwestern University Working Paper, http://www.kellogg.northwestern.edu/faculty/defusco/documents/regulating_leverage.pdf. 
Edmiston, Kelly D. (2009). "Characteristics of high-foreclosure neighborhoods in the tenth district," Economic Review, Second Quarter, Federal Reserve Bank of Kansas City, 51-75, https://www.kansascityfed.org/Publicat/EconRev/PDF/09q2edmiston.pdf.

Evans, Carol (2017). "Keeping FinTech fair," Federal Reserve Board, Consumer Compliance Outlook, Second Issue.

Fair Housing Act, https://www.law.cornell.edu/uscode/text/42/chapter-45/subchapter-I.

Fannie Mae (2018). Fannie Mae Single-Family Loan Performance Data http://www.fanniemae.com/portal/funding-the-market/data/loan-performance-data.html.

Federal Deposit Insurance Corporation, Financial Institutions Reform, Recovery and Enforcement Act of 1989 (FIRREA), available at: https://www.fdic.gov/regulations/laws/rules/8000-3100.html.

Federal Financial Institutions Examination Council, Home Mortgage Disclosure Data, various years, available at www.ffiec.gov/hmda.

Federal Financial Institutions Examination Council (2018). History of HMDA, , available at https://www.ffiec.gov/hmda/history2.htm.

Fisher, Lynn, L. Lambie-Hanson, and P. Willen (2010). "A profile of the mortgage crisis in a low-andmoderate-income community," Federal Reserve Bank of Boston, Public Policy Disc. Paper 10-6, https://www.econstor.eu/obitstream/10419/59233/1/63592871X.pdf.

Freddie Mac (2018). Freddie Mac Single Family Loan-Level Dataset, http://www.freddiemac.com/research/datasets/sf loanlevel dataset.html.

Gerardi, K. and P. Willen (2009). "Subprime mortgages, foreclosures, and urban neighborhoods," B. E. Journal of Economic Analysis and Policy, 9:3, 1-37, http://citeseerx.ist.psu.edu/viewdoc/download?doi=10.1.1.365.6589\&rep=rep1\&type=pdf.

Gerardi, Kristopher S., Stephen L. Ross and Paul Willen (2011). "Understanding the foreclosure crisis," Journal of Policy, Analysis and Management: Point-Counterpoint, 30, 382-388, https://onlinelibrary.wiley.com/doi/abs/10.1002/pam.20574.

Ghent A., R. Hernández-Murillo, and M. Owyang (2014). "Differences in subprime loan pricing across races and neighborhoods," Regional Science and Urban Economics, 48, 199-215, https://ac.elscdn.com/S0166046214000751/1-s2.0-S0166046214000751-main.pdf? tid=5749c69f-bf0d-4034abdc-45cf72fec527\&acdnat=1528210547 4418bd6bea4924990c5e6b6d86af41a8.

Glassman, Amy M. and Shanellah Verna (2016). "Disparate impact one year after inclusive communities," Journal of Affordable Housing, 25:1, 11-24, https://www.ballardspahr.com/alertspublications/articles/2016-11-01-disparate-impact-one-yearafter-inclusive-communities.aspx.

Goodman, Laurie and J. Zhu (2014). "HAMP modifications: is reset risk an issue?" Urban Institute, Washington DC, https://www.urban.org/sites/default/files/publication/32591/413125\%20\%20HAMP-Modifications-Is-Reset-Risk-an-Issue-.pdf.

Hanson, A., Z. Hawley, H. Martin, and B. Liu (2016). "Discrimination in mortgage lending: Evidence from a correspondence experiment, Journal of Urban Economics, 92:48-65, https://mediaassets.tmj4.com/document/2016/02/19/MLO\%20Discrimination HHML $32264844 \mathrm{v}$ er1.0.PDF. 
Haughwout, A., C. Mayer, and J. Tracy (2009). "Subprime mortgage pricing: The impact of race, ethnicity, and gender on the cost of borrowing." Brookings-Wharton Papers on Urban Affairs, 10, 33-63, https://www.newyorkfed.org/medialibrary/media/research/staff reports/sr368.htm .

Ho, G., and A. Pennington-Cross (2007). "The varying effects of predatory lending laws on high-cost mortgage applications," Federal Reserve Bank of St. Louis Review 89(1): 39-59, https://epublications.marquette.edu/cgi/viewcontent.cgi?article=1008\&context=fin fac.

Horne, David (1997). "Mortgage lending, race, and model specification," Journal of Financial Services Research, February, 11:1-2, 43-68.

Hoynes, H., D. Miller, and J. Schaller (2012). "Who suffers during recessions?" Journal of Economic Perspectives, 26(3): 27-48, https://gspp.berkeley.edu/assets/uploads/research/pdf/Hoynes-MillerSchaller-JEP-2012.pdf.

Jagtiani, Julapa and Catharine Lemieux (2018a). "Machine learning in FinTech lending: Evidence from the LendingClub consumer platform," Federal Reserve Bank of Philadelphia, working paper 201815, https://doi.org/10.21799/frbp.wp.2018.15.

Jagtiani, Julapa and Catharine Lemieux (2018b). "Do FinTech lenders penetrate areas that are underserved by traditional banks," Federal Reserve Bank of Philadelphia, working paper 2018-13, https://doi.org/10.21799/frbp.wp.2018.13 .

Jiang, W., A. Nelson, and E. Vytlacil (2014). "Liar's loan? Effect of origination channel and information falsification on mortgage delinquency," The Review of Economics and Statistics, 96: 1-18.

LaCour-Little M. and J. Yang (2013). "Taking the lie out of liar loans: The effect of reduced documentation on the performance and pricing of Alt-A and subprime mortgages," Journal of Real Estate Research, 35:4, 507-553, http://pages.jh.edu/jrer/papers/pdf/past/vol35n04/05.507 554.pdf.

LaCour-Little, M., C. Calhoun and W. Yu (2011). "What role did piggyback lending play in the housing bubble and mortgage collapse?" Journal of Housing Economics, 20:2, 81-100, https://ideas.repec.org/a/eee/jhouse/v20y2011i2p81-100.html.

Mayer, C., and K. Pence (2008). "Subprime mortgages: What, where and to whom?" Federal Reserve Board, Finance and Economics Discussion Series, Working Paper 2008-29, https://www.federalreserve.gov/pubs/feds/2008/200829/200829pap.pdf.

Mian, A., and A. Sufi (2009). "The consequences of mortgage credit expansion: Evidence from the U.S. mortgage default crisis," Quarterly Journal of Economics, 124:1449-96. Earlier version available at: https://www.moodys.com/microsites/crc2008/papers/cons morg cred exp.pdf

Mortgage Bankers Association (2018). National Delinquency Survey, https://www.mba.org/newsresearch-and-resources/research-and-economics/single-family-research/national-delinquencysurvey.

Munnell, Alicia H., Lynne E. Browne, James McEneaney, and Geoffrey Tootell (1992). "Mortgage lending in Boston: Interpreting the data," Federal Reserve Bank of Boston, Oct. Working Paper 92-7, https://www.bostonfed.org/publications/research-department-working-paper/1992/mortgagelending-in-boston-interpreting-hmda-data.aspx.

Munnell, Alicia H., Lynne E. Browne, James McEneaney, and Geoffrey Tootell (1996). "Mortgage lending in Boston: Interpreting the data." American Economic Review, 86:1. March. 25-53. 
New York, Office of the Attorney General, Civil Rights Bureau (2006). Assurance of discontinuance pursuant to executive law 63(15) in the matter of Countrywide home loans, Inc., November 22, https://ag.ny.gov/sites/default/files/pressreleases/archived/Countrywide\%20Assurance\%20Final\%20Signed\%20PDF.pdf.

New York, Office of the Attorney General, Civil Rights Bureau (2007). Assurance of discontinuance pursuant to executive law 63(15) in the matter of GreenPoint Mortgage Funding, Inc., March 2, https://ag.ny.gov/sites/default/files/pdfs/bureaus/civil rights/Greenpoint\%20AOD\%20Final\%20PD F.pdf.

Office of the Comptroller of the Currency (2018). Fair Lending, available at: https://www.occ.treas.gov/topics/consumer-protection/fair-lending/index-fair-lending.html

Reid, C., and E. Laderman (2009). "The untold costs of subprime lending: Examining the links among higher-priced lending, foreclosures and race in California," Federal Reserve Bank of San Francisco, Working Paper 2009-09, https://www.frbsf.org/community-development/files/wp2009-09.pdf.

Ross, S., M. Turner, E. Godfrey, and R. Smith (2008). "Mortgage lending in Chicago and Los Angeles: A paired testing study of the pre-application process," Journal of Urban Economics, 63:902-19, https://www.sciencedirect.com/science/article/pii/S0094119007000903.

Ross, Stephen L. and J. Yinger (2002). The color of credit: mortgage discrimination, research methodology, and fair-lending enforcement. Cambridge, MA. MIT Press.

Schwemm, Robert G. (2015). "Fair housing litigation after Inclusive Communities: What's new and what's not," Columbia Law Review, 115.

Sheehan, Daniel (2017). "Disparate impact liability under the Fair Housing Act after Inclusive Communities, Journal of Affordable Housing, 25:3, 391-420.

United States, Federal Trade Commission, Federal Trade Commission (2010). Press release, Final stipulated judgement and order, FTC v. Golden State Mortgage, September 20, https://www.ftc.gov/news-events/press-releases/2010/09/mortgage-lender-will-pay-15-millionsettle-ftc-charges-i and https://www.ftc.gov/sites/default/files/documents/cases/2010/09/100920gemstip.pdf.

United States, Federal Trade Commission (2016). " Big data: A tool for inclusion or exclusion?" Washington DC, https://www.ftc.gov/system/files/documents/reports/big-data-tool-inclusion-orexclusion-understanding-issues/160106big-data-rpt.pdf.

United States Department of Housing and Urban Development (2013). "Implementation of the Fair Housing Act's discriminatory effects standard," 78 Fed. Reg. 11,460-62, Feb. 15.

United States Department of Housing and Urban Development (2014). "FHA Takes Additional Steps to Provide Access to Credit for Underserved Borrowers," HUD No_14-048, available at: https://archives.hud.gov/news/2014/pr14-048.cfm.

United States Department of Housing and Urban Development, Golding, Edward L., Edward J. Szymanowski and Pamela Lee (2014). FHA at 80: Preparing for the Future, available at: http://www.huduser.org/portal//Publications/pdf/HUD-FHAAT80.pdf.

United States Department of Justice (2010). Consent order, United States v. PrimeLending, December 8, https://www.justice.gov/sites/default/files/crt/legacy/2011/02/08/primelendsettle.pdf. 
United States Department of Justice (2011). United States of America v. Countrywide Financial Corporation, U.S. District Court Central District of California, December 20, https://www.justice.gov/sites/default/files/crt/legacy/2011/12/21/countrywidecomp.pdf.

United States Department of Justice (2012). United States of America v. GFI Mortgage Bankers, Inc., filed in U.S. District Court, April 2, https://www.justice.gov/sites/default/files/crt/legacy/2012/04/03/gficomp.pdf.

United States Department of Justice (2013). United States of America v. National City Bank, filed in U.S. District Court, Western District of Pennsylvania, December 23, https://www.justice.gov/sites/default/files/crt/legacy/2013/12/24/nationalcitybankcomp.pdf.

United States Department of Justice (2012). United States of America v. Wells Fargo Bank, filed in District of Columbia, July 12, https://www.justice.gov/sites/default/files/crt/legacy/2012/07/12/wellsfargocomp.pdf..

United States Department of Treasury (2018). Making Home Affordable Data File, First Lien Loan Modification Data Set, available at https://www.treasury.gov/initiatives/financialstability/reports/Pages/mha publicfile.aspx.

United States Department of the Treasury (2009), Introduction of the home affordable modification program, Supplemental Directive 09-01, April 6.

United States Department of the Treasury (2017), Making home affordable program - Non-performing and re-performing loan sales of GSE HAMP loans and administrative clarifications, Supplemental Directive 09-01, April 14.

United States Department of the Treasury (2017). Making Home Affordable Program: Handbook for Servicers of Non-GSE Mortgages, December 21.

United States Department of the Treasury (2016). Guiding principles for the future of loss mitigation: how the lessons learned from the financial crisis can influence the path forward," July 25.

United States Financial Crisis Inquiry Commission, (2011). Final Crisis Inquiry Report (FCIC), January.

United States Government Accounting Office (2014). Troubled asset relief program: more efforts needed on fair lending controls and access for non-English speakers in housing programs," February, GAO Report 14-117 to Congressional Committees, https://www.gao.gov/assets/670/660712.pdf.

Yezer, Anthony M.J., Robert F. Phillips, and Robert P. Trost (1994). "Bias in estimates of discrimination and default in mortgage lending: the effects of simultaneity and self-selection," Federal Reserve Bank of Philadelphia, Proceedings, 197-222. 